\title{
Should a Grand Jury Subpoena Override a District Court's Protective Order?
}

\author{
Ajit V. Pai†
}

Civil discovery is designed to make all relevant information available to litigants in civil actions. ${ }^{1}$ Informative deposition testimony may often be essential to successful resolution of such disputes. When a would-be deponent is reluctant to testify before trial for fear of self-incrimination, a court may therefore promulgate a protective order to induce him to testify rather than assert his Fifth Amendment privilege.

Federal courts are empowered to issue protective orders under Federal Rule of Civil Procedure 26(c), which allows a court to "make any order which justice requires to protect a party or person from annoyance, embarrassment, oppression, or undue burden or expense." Such an order may be granted only where the requesting party demonstrates, among other things, "good cause" for its issuance. ${ }^{3}$ Protective orders often provide that only parties to the action will have access to the depositions, and that the

† B.A. 1994, Harvard University; J.D. Candidate 1997, The University of Chicago.

' See Hickman v Taylor, 329 US 495, 507 (1947) ("Mutual knowledge of all the relevant facts gathered by both parties is essential to proper litigation."); FRCP 26(b)(i) (Discovery extends to "any matter, not privileged, which is relevant to the subject matter ... if the information sought appears reasonably calculated to lead to the discovery of admissible evidence."); FRCP 26 Advisory Committee's Note to 1983 Amendment ("The purpose of discovery is to provide a mechanism for making relevant information available to the litigants."); Graham Hughes, Administrative Subpoenas and the Grand Jury: Converging Streams of Criminal and Civil Compulsory Process, 47 Vand L Rev 573, 575 (1994) ("A]ccess to information is [ ] vital in pre-litigation settings.").

${ }^{2}$ FRCP 26(c) more generally provides:

Upon motion by a party or by the person from whom discovery is sought, accompanied by a certification that the movant has in good faith conferred or attempted to confer with other affected parties in an effort to resolve the dispute without court action, and for good cause shown, the court in which the action is pending or alternatively, on matters relating to a deposition, the court in the district where the deposition is to be taken may make any order which justice requires to protect a party or person from annoyance, embarrassment, oppression, or undue burden or expense, including one or more of the following: (1) that the disclosure or discovery not be had; ... (5) that discovery be conducted with no one present except persons designated by the court; (6) that a deposition, after being sealed, be opened only by order of the court....

${ }^{3}$ Id. 
depositions will be used only within the confines of the current litigation. ${ }^{4}$

After learning of civil testimony offered in reliance on a protective order, the government may wish to obtain the protected information in order to discover possibly incriminating evidence useful to a criminal investigation. The government may properly access such information in two ways: it may move to intervene in the civil action to seek modification of the protective order, ${ }^{5}$ or it may request the testimony pursuant to a grand jury subpoena. ${ }^{6}$ Pursuit of the latter route results in a collision between the grand jury's need for information and the parties' interest in maintaining the protective order.

Federal circuits disagree over whether the grand jury subpoena should override the protective order. The Second Circuitthe first to address this issue-applies what this Comment will call the "compelling need rule." This rule generally provides that, absent a governmental showing of compelling need or extraordinary circumstances, the protective order must be preserved. Rationales for the rule include facilitation of civil dispute resolution, concern for deponents' Fifth Amendment rights, and the notion that the information would not be available but for the protective order.

The Fourth, Ninth, and Eleventh Circuits have rejected the Second Circuit's compelling need rule and hold instead that grand jury subpoenas always overcome protective orders ("the per se rule"8). They justify this rule on the ground that the public interest in investigation of criminal activity necessarily outweighs private parties' interest in resolving a civil action.

This Comment will examine and discuss the problems raised by both the compelling need and per se rules. Part I will analyze the disagreement between the circuits and point out shortcomings in the competing rules. Part II will discuss the three major interests implicated by this issue: the importance of the grand jury's function, the protection of Fifth Amendment rights, and the need to conclude civil actions fairly and efficiently. Part III will advocate a modified per se rule creating a rebuttable pre-

4 See, for example, In re Grand Jury Proceedings (Williams), 995 F2d 1013, 1014 (11th Cir 1993); Palmieri v New York, 779 F2d 861, 863-64 (2d Cir 1985).

s See FRCP 24(b). Once a motion to intervene is granted, the government may move, under FRCP 26(c), for an order modifying the protective order so that it may obtain previously protected information.

6 See In re Grand Jury Subpoena, 836 F2d 1468, 1470 (4th Cir 1988); Martindell v International Telephone \& Telegraph Corp, 594 F2d 291, 294 (2d Cir 1979).

7 See Part I.A.1.

s See Part I.A.2. 
sumption that the grand jury subpoena overrides the protective order. This presumption could be overcome upon a showing by one or both of the parties that maintenance of the protective order would serve more compelling interests. By requiring an explicit valuation of the stakes involved in civil and criminal litigation, this rule strikes the appropriate balance between the two and provides a needed focus on maximizing public welfare.

\section{CURRENT LAW AND THE SOURCES OF CONFLICT}

\section{A. The Two Competing Rules}

1. The compelling need rule.

The Second Circuit first addressed this issue in Martindell $v$ International Telephone \& Telegraph Corp. ${ }^{9}$ In Martindell, stockholders brought a derivative action against International Telephone \& Telegraph officers and directors, alleging that the defendants had squandered assets in connection with the 1970 elections in Chile. Under the shield of a Rule 26(c) protective order, the plaintiffs deposed several witnesses, including four of the defendants. The order restricted access to the depositions to the parties and limited the use of those depositions to the litigation at hand. When the government sought to obtain many of these depositions during its investigation of possible criminal violations related to the elections, the district court refused. ${ }^{10}$

On appeal, the Second Circuit affirmed the district court's enforcement of the protective order. The court noted that protective orders greatly advance the goal of securing "the just, speedy, and inexpensive determination" of civil suits. ${ }^{11}$ While conceding a public interest in obtaining all information relevant to law enforcement, the court reasoned that the government's tremendous

594 F2d 291 (2d Cir 1979).

${ }^{10}$ Id at 292-93. The court stated that the Government had "informally asked" the district judge, first by telephone and then by letter, for access to the deposition transcripts. Though no motion to intervene was ever made, nor a grand jury subpoena pursued, the district court formally denied the government's "request." Id at 293. The Second Circuit expressed amazement that the appellees had failed to raise the "obvious" threshold issue of "whether the Government, not being a party to th[e] private civil action," had a right to seek review of the district court's denial. Id. It then criticized the Government's procedural strategy: "The proper procedure [for seeking to obtain access to the deposition transcripts], as the Government should know, was either to subpoena the deposition transcripts . . . or to seek permissive intervention in the private action." Id at 294. Because the district judge's disposition of the Government's informal request "amounted to a de facto grant of permissive intervention," however, the court decided to assess the merits of the case, stating that a remand for proper compliance with procedural rules would be wasteful. Id at 294-95.

"Id at 295, quoting FRCP 1. 
investigative powers made access to civil discovery unnecessary. The court held that "absent a showing of improvidence in the grant of a Rule 26(c) protective order or some extraordinary circumstance or compelling need, ... a witness should be entitled to rely upon the enforceability of a protective order against any third parties, including the Government." ${ }^{\text {12 }}$ While Martindell did not involve a grand jury subpoena,$^{13}$ the court's respect for protective orders set the course for the future development of Second Circuit law.

The Second Circuit reaffirmed and explained Martindell in Palmieri $v$ New York, ${ }^{14}$ which involved concurrent criminal and civil antitrust litigation. During settlement proceedings, the civil litigants requested, and the presiding magistrate granted, protective orders sealing all discovery materials. The Attorney General of New York subsequently sought access to these materials, first by filing motions to intervene and to modify the protective order, and later by serving the civil plaintiff with a grand jury subpoena. Eventually, a district judge granted the Attorney General's motion to modify the orders and gave the state access to settlement negotiations and terms. ${ }^{15}$

The Second Circuit reversed on appeal, holding that the parties' reliance on the protective orders created a presumption in favor of the orders' enforcement. Extending Martindell's reasoning, the court found that the orders had not been improvidently granted, and that the state had not demonstrated a compelling need or an extraordinary circumstance justifying access to the materials. ${ }^{16}$

The court revisited the issue in In re Grand Jury Subpoena Duces Tecum Dated April 19, 1991, ${ }^{17}$ a case arising out of Eastern Airlines' 1989 bankruptcy filing. Shortly after the filing, a bankruptcy judge appointed an examiner to scrutinize several of Eastern's allegedly fraudulent pre-filing transactions. Parties to these transactions (including Eastern) told the examiner that neither documents nor witnesses would be produced absent an

${ }^{12}$ Id at 296.

${ }^{13}$ See note 10.

${ }^{14} 779$ F2d 861 (2d Cir 1985).

${ }^{15}$ Id at 864.

${ }^{36}$ The state had asserted that the protective order was improvident because it facilitated criminal conduct. The court noted that "the requisite inquiry is whether the issuing official ... reasonably should have recognized a substantial likelihood that the settlement would facilitate or further criminal activity." The court did not discuss what other circumstances might constitute improvidence, or what the standard for demonstrating compelling need or extraordinary circumstances might be. See id at 865-66.

${ }^{17} 945$ F2d 1221 (2d Cir 1991). 
assurance of confidentiality. Employing a bankruptcy analog to Rule 26(c) ${ }^{18}$ the examiner agreed to seal all matters in the proceeding, laboring as he was "under enormous pressure to expedite his investigation in the interests of creditors who were owed billions of dollars, the traveling public and thousands of Eastern employees whose jobs depended on a prompt reorganization."19

In 1991, federal prosecutors obtained a subpoena duces tecum requiring the examiner to produce all documents related to the Eastern bankruptcy proceeding. A district judge refused the examiner's motion to quash, and the examiner appealed.

Again applying Martindell, the Second Circuit concluded that the district judge had mistakenly denied the motion to quash, as he had failed to make an explicit finding on whether the protective order had been improvidently granted or whether the government had met the burden of showing a compelling need or an extraordinary circumstance. ${ }^{20}$

2. The per se rule.

a) The Fourth Circuit. The Fourth Circuit rejected the compelling need rule in In re Grand Jury Subpoena, ${ }^{21}$ a case involving the criminal investigation of a bankrupt Maryland financial institution. In affirming a district court's refusal to quash the subpoenas of officers and directors of the savings and loan's parent and affiliates, the Fourth Circuit outlined the three interests at stake: "the authority of a grand jury to gather evidence in a criminal investigation; the deponents' right against self-

${ }^{28}$ Id at 1224. 11 USC $\$ 107(b)(1994)$ of the Bankruptcy Code establishes a presumption of public access to all papers filed in bankruptcy court. However, an important exception is made: "On request of a party in interest, the bankruptcy court shall, and on the bankruptcy court's own motion, the bankruptcy court may (1) protect an entity with respect to a trade secret or confidential research, development, or commercial information." Id. that

Bankruptcy Rule 9018 (1993), the procedural relative of 11 USC $\S 107(\mathrm{~b})$, provides

On motion or on its own initiative, with or without notice, the court may make any order which justice requires (1) to protect the estate or any entity in respect of a trade secret or other confidential research, development, or commercial information, (2) to protect any entity against scandalous or defamatory matter contained in any paper filed in a case under the Code, or (3) to protect governmental matters that are made confidential by statute or regulation.

See also In re Orion Pictures Corp, 21 F3d 24, 27 (2d Cir 1994) (detailing the process of issuing protective orders under bankruptcy rules); In re Handy Andy Home Improvement Centers, Inc, 199 BR 376, 380-81 (N D Il 1996) (same).

${ }^{29}$ In re Grand Jury Subpoena Duces Tecum Dated April 19, 1991, 945 F2d at 1222.

${ }^{2}$ Id at 1226. The court again failed to provide a standard for discharging this burden.

${ }^{21} 836$ F2d 1468 (4th Cir 1988). 
incrimination; and the goals of liberal discovery and efficient dispute resolution in civil proceedings. ${ }^{22}$ It then attempted to address these concerns.

The court recognized an overriding interest in grand jury access to all relevant information ${ }^{23}$ because such information could aid investigations and provide impeachment evidence. ${ }^{24}$ It reasoned that protective orders undermine this interest by excluding useful testimony from public and governmental view, and that such orders have the potential to "cause the absurd result of shielding deponents from prosecutions for perjury." 25

The court further determined that allowing a grand jury subpoena to override a protective order would not adversely affect deponents' Fifth Amendment rights. It noted that "[d]eponents were entitled to rely only on their own silence or a grant of immunity to protect their rights, otherwise they risked waiving those rights. ${ }^{\text {"26 }}$ Moreover, it reasoned, a protective order issued to safeguard a deponent's Fifth Amendment privilege effectively usurps the executive branch's exclusive ${ }^{27}$ power to grant immunity. ${ }^{28}$

While acknowledging that protective orders could aid civil discovery, the Fourth Circuit questioned whether they substantially facilitate civil dispute resolution. Because protective orders do not confer immunity, they cannot compel a witness to testify. ${ }^{29}$ Additionally, because they can be violated, modified, leaked, or undermined by deponents' assertion of their Fifth Amendment privilege, deponents are unlikely to rely on them. ${ }^{30}$

Finally, the court stated that courts hearing civil cases have alternatives to protective orders that permit successful dispute resolution, including holding a pretrial hearing to expose frivolous assertions of the Fifth Amendment privilege, shifting the

\footnotetext{
22 Id at 1471.

${ }^{23}$ Id at 1475 n 10 ("It is misguided to contend that the government's ability to gather other evidence of criminal misconduct undermines this interest. The grand jury has the right to gather all relevant evidence.").

${ }^{21}$ Id at 1475 ("[T]he government has an interest in obtaining this information for purposes of impeachment should the deponents testify in a manner materially inconsistent with their deposition testimony in any future criminal trial.").

${ }^{*}$ Id.

${ }^{2}$ Id at 1471.

27 See notes 86,88 .

${ }^{2}$ In re Grand Jury Subpoena, 836 F2d at 1475. See also notes 86-90 and accompanying text.

${ }^{2}$ Notably, even the Second Circuit has expressed such doubts. See Andover Data Services, Inc v Statistical Tabulating Corp, 876 F2d 1080, 1084 (2d Cir 1989). See also note 83.

${ }^{30}$ In re Grand Jury Subpoena, 836 F2d at 1475-76.
} 
burden of proof, and staying civil proceedings until the completion of a criminal investigation or trial. ${ }^{31}$

b) The Eleventh Circuit. The Eleventh Circuit adopted the per se rule in In re Grand Jury Proceedings (Williams). ${ }^{32}$ In this case, the plaintiff sued his employer, an insurance company, to recover commissions allegedly due on policies he had sold. The insurance company defended by arguing that the plaintiff had offered potential policyholders a portion of his would-be commission as an inducement to purchase insurance, a scheme known as "rebating." ${ }^{33}$

When the plaintiff initiated the civil suit, a grand jury had been investigating whether his alleged rebating violated the mail and wire fraud statutes. ${ }^{34}$ Fearing self-incrimination should his civil discovery responses become available to the grand jury, the plaintiff moved for, and received, a protective order that limited the use of his testimony to the civil suit. When the grand jury issued a subpoena duces tecum to the civil court reporter for the notes of the plaintiff's deposition, the plaintiff moved to quash the subpoena. The district judge, applying the Second Circuit's compelling need rule, ruled that the plaintiff should have been able to rely on the protective order, and granted the motion to quash. The government appealed..$^{35}$

The Court of Appeals reversed the district court, stating that "the desire to conclude a civil dispute quickly . . . is not a compelling reason for interfering with the grand jury by refusing to enforce its subpoenas."36 It reasoned that the grand jury's wide scope of power, ${ }^{37}$ the district court's inability to confer immunity ${ }^{38}$ and the impracticability of the compelling need rule ${ }^{39}$ justified enforcing the grand jury subpoena.

c) The Ninth Circuit. The Ninth Circuit recently embraced the per se rule in In re Grand Jury Subpoena Served on Meserve,

\footnotetext{
${ }^{31}$ Id at 1476-77.

32995 F2d 1013, 1020 (11th Cir 1993).

${ }^{33}$ "Rebating" contravened both Georgia law and the plaintiffs employment contract. Id at 1013.

34 18 USC $\S \S 1341,1343$ (1994). See In re Grand Jury Proceedings (Williams), 995 F2d at 1013-14.

35 In re Grand Jury Proceedings (Williams), 995 F2d at 1014-15.

${ }^{36}$ Id at 1017.

${ }^{37}$ Id at 1015-16 (detailing the grand jury's "sweeping powers to investigate allegations of criminal behavior").

${ }^{3 *}$ Id at 1017 ("[F]ederal courts lack the power to provide witnesses with the broad protection [against self-incrimination] that witnesses seek.").

${ }^{29}$ Id at 1018 (rejecting the compelling need rule as an "administratively unworkable" test that "defies construction").
} 
Mumper \& Hughes ${ }^{40}$ In this case, insurance companies, bringing suit against a private corporation for fraudulent billing, settled after lengthy discovery. The settlement was contingent on issuance of an order protecting all discovery material. When a grand jury subsequently subpoenaed the law firm of one of the insurance companies, seeking to obtain copies of documents produced during civil discovery, the defendant moved to quash the subpoena. Following the district court's refusal to quash, the defendant appealed. ${ }^{41}$

The Ninth Circuit, in a succinct opinion, found the Eleventh Circuit's rationale for the per se rule in In re Grand Jury Proceedings (Williams) persuasive. It agreed with the Eleventh Circuit's deference to the grand jury's constitutional and historical importance, ${ }^{42}$ as well as the conclusion that Rule 26(c) had not been intended to allow protective orders to impede grand jury proceedings. ${ }^{43}$

\section{B. Criticisms of the Two Rules}

1. The compelling need rule.

The compelling need rule is susceptible to several criticisms. Most importantly, neither Martindell nor its progeny provide precise standards regarding what constitutes a "compelling need" or an "extraordinary circumstance." Additionally, the cases have not explained the conditions under which a district judge's grant of a protective order might be considered "improvident." ${ }^{44}$ Indeed, none of the three major Second Circuit decisions (Martindell, Palmieri, and In re Grand Jury Subpoena Duces Tecum Dated April 19, 1991) makes clear why the government failed to present a compelling need; the court merely asserts that "none of [these conditions] appear here. ${ }^{35}$ Such vague standards might impel would-be deponents to exercise their Fifth Amendment privilege,

*3 62 F3d 1222, 1226)(9th Cir 1995).

11 Id at 1222-23.

12 See id at 1226 ('The Eleventh Circuit's dogged devotion to the grand jury's constitutional and historical stature [ ] suggests that a per se rule in favor of the grand jury subpoena is not only the practical result, but also the proper one.").

${ }^{3}$ Id.

" One commentator has suggested that "[t]he granting court will know if the order was improvident in the event that the protective order noticeably enabled the furtherance of a crime." See Marc Youngelson, The Use of 26(c) Protective Orders: "Pleading the Fifth" Without Suffering "Adverse" Consequences, 1994 Ann Surv Am Law 245, 275 (1995). Yet even this "standard" is vague and, as this Comment argues later, underinclusive.

${ }^{45}$ Martindell, 594 F2d at 296. See also Palmieri, 779 F2d at 866; In re Grand Jury Subpoena, 945 F2d at 1224 . 
and thus may significantly retard civil discovery whether or not a grand jury subpoena has been issued. ${ }^{46}$

The "improvidently granted" standard is similarly vague. Failure to define this standard leaves uncertain what evidence the reviewing judge should consider when deciding whether the trial judge has improvidently granted a protective order. On one hand, if the reviewing judge considers only evidence available to the trial judge when he issued the protective order, the grand jury's need for the information would rarely affect the analysis, since the issuing judge would not know of the government's need. ${ }^{47}$ Indeed, with nothing on the record at the time of issuance to counter the parties' arguments in favor of the protective order, the government could never demonstrate improvidence. On the other hand, if the reviewing judge also considers evidence available after the issuance of the protective order, the parties' expectations-supposedly accorded deference by the Second Circuit-. may be compromised by the grand jury's interest in obtaining the information. The test effectively requires nothing more than a compelling need or an extraordinary circumstance. ${ }^{48}$

In addition, application of the rule presents several practical problems. The foremost is what one circuit has deemed a "Hobson's choice." When a district judge issues a protective order to induce a deponent's testimony-often explicitly assuring

${ }^{45}$ Uncertainty in modification standards might increase the risk of outside access to protected testimony enough to lead rational deponents to assert the Fifth Amendment privilege. Risk-averse deponents fearing government access to their testimony will be loath to offer information under the "shield" of a protective order if that shield can be pierced for incompletely specified reasons. Thus, facilitating civil litigation may depend heavily on the clarity of protective order modification standards.

${ }^{47}$ The Fourth Circuit voiced this concern in In re Grand Jury Proceedings (Williams), 995 F2d at 1018-19. It also noted that the government would usually not disclose this need for the evidence prior to the grant of a protective order "because in all probability (1) the government would not have been a party to the civil proceeding [at that point], and (2) unless it was monitoring the proceeding, it would not have known that an application for the order had been made." Id at $1018 \mathrm{n} 12$.

${ }^{48}$ Id at $1019 \mathrm{n} 13$ ("If . . . the term 'improvidently granted' does not have its usual meaning, but refers to an analysis that considers evidence adduced since the entering of the protective order, then the term loses independent meaning and collapses into the definition of 'exceptional circumstances' or 'compelling need.").

${ }^{*}$ See In re Grand Jury Proceedings (Williams), in which the Eleventh Circuit stated that the compelling need rule

creates a Hobson's choice when, after the judge has induced the witness to incriminate himself by promising to enforce a protective order, the government demonstrates compelling need for the witness' testimony. The judge must choose between (1) going back on his word (thus breeding disrespect for the law in the eyes of the witness, if not the public in general) by honoring the grand jury subpoena, and (2) denying the public its "right to every man's evidence." Either way, the public suffers.

Id at 1019-20. 
the deponent that such testimony will remain confidential-he faces a lesser-of-two-evils decision: if the government later demonstrates a compelling need or extraordinary circumstance, the judge must either rescind or modify the protective order, and frustrate the deponent's reasonable expectation that his testimony would be protected, or decline the government's request, making the "test" little more than a formality. In either case, the court undermines expectations that have been formed in reliance on the rule. The Second Circuit's apparent "solution" to this dilemma has been to reject most claims of compelling need or extraordinary circumstances. Indeed, the Second Circuit has never allowed a grand jury subpoena to override a protective order. ${ }^{50}$

The compelling need rule also frustrates the practice of prosecutors. A government attorney attempting to meet the test inevitably faces two competing constraints. The first is the procedural and historical interest in preserving the secrecy of grand jury proceedings. ${ }^{51}$ The second is the need to produce enough evidence from the grand jury's investigation to demonstrate a compelling need or an extraordinary circumstance justifying compliance with the subpoena..$^{52}$ The quantum of evidence that a prosecutor must reveal to the trial judge is not defined, leaving the prosecutor in the untenable position of guessing just how much he must violate grand jury secrecy to override the protective or$\operatorname{der}^{53}$

\footnotetext{
${ }^{50}$ But see United States $v$ Davis, 702 F2d 418, 422-23 (2d Cir 1983), where the Second Circuit affirmed a district court's order to produce testimony and documents subpoenaed by a grand jury, despite a claim of confidentiality, because the claim was not a formal Rule 26(c) protective order and because there was "no indication that [the deponent] agreed to testify only in reliance on the "understanding." Id at 422.

${ }^{51}$ The procedural interest in grand jury secrecy derives from FRCrP 6(e)(2), which provides that "[a] grand juror, [court personnel, or] an attorney for the government ... shall not disclose matters occurring before the grand jury." Additionally, several Supreme Court decisions have reinforced the traditional need for secrecy in grand jury proceedings. See United States $v$ Williams, 504 US 36, 48 (1992) (noting that the grand jury "deliberates in total secrecy"); United States $v$ Sells Engineering, Inc, 463 US 418, 424-25 (1983) (observing that grand jury secrecy is as important for the protection of the innocent as for the pursuit of the guilty"), quoting United States $v$ Johnson, 319 US 503, 513 (1943); and United States $v$ Procter \& Gamble Co, 356 US 677, 681 (1958) (affirming the "long-established policy that maintains the secrecy of the grand jury proceedings in the federal courts").

${ }^{52}$ See In re Grand Jury Proceedings (Williams), 995 F2d at 1019 ("Certainly, the prosecutor must avoid disclosing grand jury proceedings. Yet, the prosecutor must show some such evidence in order to enforce the subpoena.").

${ }^{*}$ See United States v R. Enterprises, Inc, 498 US 292, 299 (1991) ("Requiring the Government to explain in too much detail the particular reasons underlying a subpoena threatens to compromise 'the indispensable secrecy of grand jury proceedings."), quoting Johnson, 319 US at 513. The Eleventh Circuit pointed out that "[i]t is not clear whether the prosecutor has a single opportunity to be heard, and must therefore guess how much evidence to produce, or if the prosecutor may merely reveal the investigation a piece at a
} 
Further, shortcomings of the compelling need rule aggregate when multiple courts become involved. For instance, in In re Grand Jury Subpoena, deponents in a federal civil proceeding in Virginia requested a protective order that would prevent their testimony from becoming available to a Maryland grand jury making an independent criminal investigation of the same matter ${ }^{54}$ Shortly after the Virginia judge granted the protective order, the Maryland grand jury subpoenaed transcripts of several depositions. The deponents appealed after the Maryland district court refused to quash the subpoenas. By pitting the grand jury's interest in obtaining evidence against the parties' interest in maintaining the protective order, and one judge against another, the Second Circuit rule may create judicial conflict incapable of satisfactory resolution..$^{55}$

Finally, the compelling need rule may hinder prosecutions. It may impede criminal investigations, since testimony volunteered in the civil action may be critical to a grand jury deliberating on whether criminal activity has occurred. ${ }^{56}$ It may undermine the governmental interest in obtaining the testimony for purposes of impeachment in future criminal trials. It also may shield deponents from perjury prosecutions, since the public cannot otherwise access false testimony. ${ }^{57}$

\section{The per se rule.}

The per se rule similarly invites criticism. The most obvious is its inherent inflexibility. As this Comment later discusses, in certain circumstances both private parties and the public may be better served by maintenance of the protective order and completion of civil litigation. ${ }^{58}$ Because resolution of the civil dispute may be preferable to enforcement of the grand jury subpoena, courts need standards to determine when such a condition exists, not a rule that results in unexcepted refusal to uphold the protective order.

Another shortcoming of the per se rule is that it dampens, if not destroys, deponents' incentives to testify in civil proceedings.

time until it convinces the court that the grand jury's need is sufficient." In re Grand Jury Proceedings (Williams), 995 F2d at 1019.

s 836 F2d at 1469-70. See also text accompanying notes 21-31.

$\approx$ If different courts rule on this issue, the Hobson's choice problem is partly avoided. See note 49.

${ }^{56}$ See In re Grand Jury Subpoena, 836 F2d at 1475 ("Uncoerced testimony given in a civil action may provide important and relevant information to a grand jury investigation.").

5 Id.

ss See Part III.B. 
A deponent fearing criminal liability may not volunteer testimony under the "protection" of a protective order if he knows that a grand jury could subpoena that testimony in assessing criminal liability. It is quite possible that the would-be deponent might instead assert his Fifth Amendment privilege and remain silent, ${ }^{59}$ not only diverting the grand jury's inquiry but delaying resolution of the civil dispute as well. ${ }^{60}$

\section{ANALYSIS OF COMPETING POLICIES}

The conflicting jurisprudence among the circuit courts reflects disagreement about how best to reconcile the different interests implicated when a grand jury subpoena clashes with a protective order. These interests can be separated into three categories: the importance of the grand jury's function, the Fifth Amendment implications in this particular context, and the need for effective resolution of civil disputes. This Part discusses each of these interests in turn.

\section{A. The Importance of the Grand Jury's Function}

In contrast to the modern procedural device of the protective order, the grand jury's lineage begins in old England. ${ }^{61}$ Faith in the grand jury derived from its status as an independent arbiter of potential criminal liability ${ }^{62}$ This is precisely why the grand jury was vested with tremendous powers: it could further the public interest while minimizing the potential for governmental interference with or abuse of the investigative process.

se notes 92-102 and accompanying text.

${ }^{6}$ See generally Part II.B and Part II.C.

${ }^{61}$ See Hannah $v$ Larche, 363 US 420, 490 (1960) (Frankfurter concurring) (noting that the grand jury is "rooted in long centuries of Anglo-American history"); R.H. Helmholz, The Early History of the Grand Jury and the Canon Law, $50 \mathrm{U}$ Chi L Rev 613, 613 (1983) (pinpointing Henry I's Assize of Clarendon in 1166 as the origin of the modern grand jury); Marvin E. Frankel and Gary P. Naftalis, The Grand Jury: An Institution on Trial 6. 7 (Hill and Wang 1977); Sara Sun Beale and William C. Bryson, Grand Jury Law and Practice § 1:02 at 4-5 (Callaghan 1986). For a general history of the early grand jury and medieval criminal procedure, see Leonard W. Levy, Origins of the Fifth Amendment: The Right Against Self-Incrimination 3-42 (Macmillan 2d ed 1986).

* See Grand Jury Reform, Hearings on HR 94 before the Subcommittee on Immigration, Citizenship, and International Law of the House Committee on the Judiciary, 95th Cong, 1st Sess 57 (1977) (statement of Professor John Anthony Scott, legal historian, Rutgers U School of Law) ("The critical and ignored fact is that the common law grand jury was valued as an independent body; when it investigated it was in the name of the community and not of the king."). For the same reason, colonial America held the institution in high regard. Id at 68 ("The value of the grand jury as a shield to the ordinary subject against oppressive government was grasped nowhere with more certainty than in colonial America."). 
The Fifth Amendment to the United States Constitution begins with the adoption of this ancient English institution: ${ }^{.3}$ "No person shall be held to answer for a capital, or otherwise infamous crime, unless on a presentment or indictment of a Grand Jury." ${ }^{\text {c64 }}$ As the Supreme Court has observed, the grand jury's inclusion within the Bill of Rights, as opposed to the seven Articles of the Constitution, demonstrates the fundamental premise behind its existence: it is an institution independent of the government and the people, ${ }^{65}$ a "constitutional fixture in its own right."

Even after more than two hundred years of operation, the American grand jury's functions have remained fairly constant: first, investigating whether criminal activity has transpired and, if so, identifying the responsible parties; ${ }^{67}$ and second, determining whether indictments should be issued against the accused. ${ }^{68}$

To achieve these ends, the grand jury is vested with extensive investigatory powers, and substantively is neither limited nor supervised by the courts. ${ }^{69}$ Its legal separation from the judiciary is reinforced by both the scope and nature of the grand jury's power: "Unlike [a c]ourt, whose jurisdiction is predicated on a specific case or controversy, the grand jury 'can investigate

ॠ Interestingly, England abolished the grand jury in 1948. See Hughes, 47 Vand L Rev at $581 \mathrm{n} 24$ (cited in note 1).

or US Const, Amend V.

${ }^{65}$ See United States $v$ Williams, 504 US 36, 47 (1992) (positing that "the whole theory of its function is that it belongs to no branch of the institutional Government, serving as a kind of buffer or referee between the Government and the people"); Stirone $v$ United States, 361 US 212, 218 (1960) ("The very purpose of the requirement that a man be indicted by grand jury is to limit his jeopardy to offenses charged by a group of his fellow citizens acting independently of either prosecuting attorney or judge.”).

${ }^{66}$ United States $v$ Chanen, 549 F2d 1306, 1312 (9th Cir 1977), quoting Nixon v Sirica, 487 F2d 700, 712 n 54 (DC Cir 1973). See also Grand Jury Reform Hearings at 57 (cited in note 62) ("The grand jury was written into the Bill of Rights because it became, in common law England and particularly in the colonies, a leader and symbol of community resistance to arbitrary and oppressive state power."); id at 77 ("The grand jury was not brought into being by the Founding Fathers to preside over the persecutions and inquisitions of Government against the citizen. It was, on the contrary, designed to protect the citizens against the persecutions of the Government.").

${ }^{77}$ See Beale and Bryson, Grand Jury Law and Practice $\$ 1: 07$ at 35 (cited in note 61). The authors note that "[a]lthough the indicting function of the grand jury is no longer of much importance in many jurisdictions, the investigative grand jury is playing an increasingly important role in both state and federal cases." Id § 1:01 at 3.

${ }^{6 *}$ See Branzburg $v$ Hayes, 408 US 665, $687-88$ (1972). Incidentally, it is noteworthy that neither Rule 26(c) itself nor the Advisory Committee notes implies a Congressional or Committee intention to alter the institutional function of the grand jury as it has developed over time. See In re Grand Jury Subpoena Served on Meserve, Mumper \& Hughes, 62 F3d at 1226; In re Grand Jury Proceedings (Williams), 995 F2d at 1017.

${ }^{69}$ Williams, 504 US at 47 (noting that the role of the judicial branch in the functioning of the grand jury has traditionally "been confined to the constitutive one of calling the grand jurors together and administering their oaths of office"). 
merely on suspicion that the law is being violated, or even just because it wants assurance that it is not.' ${ }^{270}$ Once sworn, grand jurors may initiate investigations, ${ }^{71}$ subpoena witnesses (who have no right to the assistance of counsel $\left.{ }^{72}\right),{ }^{73}$ and operate without judicial interference. So reluctant is the Supreme Court to limit grand jury procedures that it has declined to apply to grand jury proceedings the exclusionary rule ${ }^{74}$ the hearsay rule ${ }^{75}$ the requirement of probable cause prior to issuance of subpoenas, ${ }^{76}$ and the government's obligation to disclose substantial exculpatory evidence in its possession. ${ }^{77}$ Recognizing this virtually plenary power, courts have traditionally accorded the grand jury great latitude in obtaining information, as shown by the wellknown dictum that "the public . . . has a right to every man's evidence." 78

Unlike the grand jury, the Federal Rules of Civil Procedure are recent creations, ${ }^{79}$ intended "to secure the just, speedy, and

${ }^{70}$ United States $v$ R. Enterprises, Inc, 498 US 292, 297 (1991), quoting United States $v$ Morton Salt Co, 338 US 632, 642-43 (1950).

${ }^{71}$ See United States $v$ Dionisio, 410 US 1, 15 (1973) ("[Grand] jurors may act on tips, rumors, evidence offered by the prosecutor, or their own personal knowledge."); Hughes, 47 Vand L Rev at 576-77 (cited in note 1) ("[The grand jury's] historical freedom to begin an inquiry based on mere hearsay, rumor, or even whim has been stoutly defended and upheld in modern cases.").

${ }_{72}$ See United States v Mandujano, 425 US 564, 581 (1976) ("A witness before a grand jury cannot insist, as a matter of constitutional right, on being represented by his counsel ....' Under settled principles the witness may not insist upon the presence of his attorney in the grand jury room."), quoting In re Groban, 352 US 330, 333 (1957).

${ }^{73}$ Branzburg, 408 US at 688.

${ }^{24}$ United States $v$ Calandra, 414 US 338, 349-50 (1974) (refusing to apply the exclusionary rule due to "the potential injury to the historic role and functions of the grand jury"); Hughes, 47 Vand L Rev at $577 \mathrm{n} 13$ (cited in note 1) ("While the grand jury itself may not violate a witness's constitutional rights, it need not conduct an exclusionary rule inquiry into the possibility of a prior violation.").

${ }^{75}$ Costello v United States, 350 US 359, 364 (1956) (rejecting the application of the hearsay rule because it "would run counter to the whole history of the grand jury institution, in which laymen conduct their inquiries unfettered by technical rules").

${ }^{16}$ Dionisio, 410 US at 15 . See also Hughes, 47 Vand $\mathrm{L}$ Rev at 576 \& $\mathrm{n} 8$ (cited in note 1) (explaining that the rule "is based on the Supreme Court's refusal to equate grand jury subpoenas and their consequences with the searches and seizures that are the subject of the Fourth Amendment").

${ }^{n}$ Williams, 504 US at 55 (Courts have no authority to require prosecutors to disclose exculpatory evidence to grand juries.).

${ }^{73}$ Branzburg, 408 US at 688 (citing this "longstanding principle" of the grand jury). See also id at 701 ("A grand jury investigation "is not fully carried out until every available clue has been run down and all witnesses examined in every proper way to find if a crime has been committed."'), quoting United States v Stone, 429 F2d 138, 140 (2d Cir 1970); In re Grand Jury Subpoena, 836 F2d at 1475 n 10 ("The grand jury has the right to gather all relevant evidence.").

$7_{79}$ Pursuant to the Rules Enabling Act, 48 Stat 1064 (1934), codified at 28 USC $\S \S$ 2072-74 as subsequently revised, the rules became effective on September 16, 1938, when Congress adjourned without taking any adverse action against them. See Charles Alan 
inexpensive determination of every action. ${ }^{n 80}$ Within this framework, the Rule 26(c) protective order is designed to prevent oppression of and burdens on parties and persons by protecting sensitive information in discovery from outside view (or, sometimes, even from opposing parties). Such an order ideally facilitates resolution of the civil dispute by disclosing relevant information. Rule 26(c) affords a district judge wide discretion, allowing him to make any order "which justice requires" to effectuate the above-stated goal.

\section{B. Fifth Amendment Implications}

The primary function of protective orders in this context is to induce deponents to testify by shielding their testimony from outside view. However, because a protective order cannot adequately protect deponents from self-incrimination, some deponents will assert the privilege anyway. ${ }^{81}$ Further, the concern that overriding a protective order might adversely affect a deponent's Fifth Amendment rights ${ }^{82}$ is misplaced.

1. The compelling need rule cannot adequately protect the deponent's Fifth Amendment rights.

A court may attempt to elicit ${ }^{83}$ a reluctant deponent's testimony by issuing a protective order that effectively immunizes him from criminal prosecution. ${ }^{84}$ However, a protective order cannot protect sufficiently a deponent's right against selfincrimination. As the Fourth Circuit has noted, 'deponents' fifth amendment right against self-incrimination [does] not require,

Wright, Law of Federal Courts $§ 62$ at 428 (West 5th ed 1994).

${ }^{20}$ FRCP 1.

${ }^{21}$ See, for example, Robert Heidt, The Conjurer's Circle: The Fifth Amendment Privilege in Civil Cases, 91 Yale L J 1062, 1096 (1982):

The court's inability to compel an incriminatory response would not necessarily negate the value of the protective order if in fact the order persuaded potential invokers in a civil suit to waive the privilege and respond. From the perspective of the potential invoker, however, the relative costs and benefits of invoking or waiving the privilege are not significantly altered by a protective order.

* See Youngelson, 1994 Ann Surv Am Law at 269-71 (cited in note 44).

${ }^{*}$ A court may not use a protective order to compel the testimony of an unwilling witness asserting a valid Fifth Amendment claim. See, for example, Andover Data Services, Inc $v$ Statistical Tabulating Corp, 876 F2d 1080, 1084 (2d Cir 1989). The Second Circuit noted, however, that the holding in Andover did not prohibit a court from using a protective order when witnesses volunteer testimony in reasonable reliance on it. Id.

This is especially the case where the protective order expressly excludes any law enforcement entities from access to the protected testimony. See, for example, Palmieri, 779 F2d at 863. 
nor may it depend on, the shield of civil protective orders. ${ }^{385}$ In other words, a deponent in civil proceedings has only two options if he wishes to preserve his right against self-incrimination: seek immunity or assert the Fifth Amendment privilege. Protective orders cannot effect the first choice, and cannot preclude the latter.

Statutory and separation of powers principles leave federal courts a lacuna in the power to immunize witnesses. Federal law vests the power to grant immunity in executive branch officers. ${ }^{86}$ This authority-a classic manifestation of prosecutorial discretion $^{87}$-is inextricably linked to the executive's fundamental obligation to enforce the law. Immunizing a witness, thus a uniquely executive power ${ }^{88}$ is not a judicial one. ${ }^{89}$ Because deponents volunteering testimony in reliance on the protective order are shielded (at least temporarily) from any subsequent criminal investigation, a court issuing such an order effectively, and improperly, confers immunity. Indeed, the court is interfering with the executive's responsibility to "balance the public interest in

${ }^{85}$ In re Grand Jury Subpoena, 836 F2d at 1471.

${ }^{66}$ Government attorneys may offer immunity to a witness who has refused, or is likely to refuse, to testify based on the Fifth Amendment privilege against selfincrimination. Immunity may be granted when the Government believes the testimony or other information from the witness may be necessary to the public interest. If the witness refuses to testify nonetheless, the prosecutors may ask a court to compel such testimony. See 18 USC $\$ 6003$ (1994) (granting only the United States Attorney and members of the Department of Justice the power to request "an order requiring [a witness] to give testimony or provide other information which he refuses to give or provide on the basis of his privilege against self-incrimination"). See also Ryan $v$ Commissioner of Internal Revenue, 568 F2d 531, 540 (7th Cir 1977) ("[T] he immunity statute delegates the authority to obtain an immunity grant solely to the executive branch of government. The United States Attorney determines whether a grant of immunity is in the public interest, and the district court may not review that judgment.").

${ }^{81}$ See Heidt, 91 Yale L J at 1101 (cited in note 81) ("The executive's control over use immunity follows naturally from its control over the decision to prosecute.").

${ }^{83}$ Note, however, that congressional committees also may grant use immunity to those called to testify in legislative proceedings, assuming a number of procedural requirements are met. See 18 USC $\$ 6005$ (1994).

* See Pillsbury Co $v$ Conboy, 459 US 248, 261 (1983) ("No court has authority to immunize a witness. That responsibility, as we have noted, is peculiarly an executive one, and only the Attorney General or a designated officer of the Department of Justice has authority to grant use immunity."); In re Grand Jury Proceedings (Williams), 995 F2d at 1017 ("Federal courts [ ] have no authority to grant witnesses-including those who testify under a Rule 26(c) protective order-such use immunity."); In re Stephen TSE, 748 F2d 722, 725 (1st Cir 1984) (Given the "essentially ministerial function the court exercises in issuing [an immunity] order to testify, [a district court] does not review the executive branch's decision that immunity is in the public interest, but rather only ascertains whether the statutory procedures were followed."); Heidt, 91 Yale L J at 1101 n 155 (cited in note 81) ("[T]he court's sole function is to ascertain whether the Justice Department has complied with the statute; it does not review the merits of the Justice Department's decision."). 
confidentiality against the interest in effective criminal investigation." 90

Furthermore, protective orders are unable to prevent deponents from invoking the Fifth Amendment privilege: As noted above, some deponents will assert the privilege against selfincrimination even if the court has issued a protective order. ${ }^{91}$ This strongly suggests that the protective order may not adequately protect a deponent from self-incrimination. Indeed, given the severity of the potential consequences if testimony offered in a civil case is used in a subsequent criminal investigation, it should come as no surprise that many deponents will not rely on a procedural device to protect them from self-incrimination.

Regardless of the rule that courts apply, there are a variety of reasons why deponents will assert the privilege if anything less than full and permanent confidentiality is assured. ${ }^{92}$ First, a protective order may be modified even under the compelling need rule. ${ }^{93}$ While modification may be conditioned on a governmental showing of compelling need or extraordinary circumstances, anything less than absolute certainty in the sanctity of a protective order is likely to lead deponents to invoke the Fifth Amendment privilege at the outset. ${ }^{94} \mathrm{~A}$ deponent concerned about his own self-incriminating testimony can take little solace from the purportedly higher threshold of the compelling need rule when the government shows such a need. Instead, deponents may simply assert the privilege at the first opportunity, rather than take the

${ }^{50}$ In re Grand Jury Subpoena, 836 F2d at 1475.

"12 See text accompanying notes 26-30.

92 See, for example, Pillsbury, 459 US at 261 ("Unless the grant of immunity assures a witness that his incriminating testimony will not be used against him in a subsequent criminal prosecution, the witness has not received the certain protection of his Fifth Amendment privilege that he has been forced to exchange.") (emphasis added).

${ }^{*}$ All courts, including the Second Circuit, agree that parties to the action or third parties may move for, and the court may grant, a modification of the protective order. See for example, In re "Agent Orange" Product Liability Litigation, 821 F2d 139, 145 (2d Cir 1987) ("It is undisputed that a district court retains the power to modify or lift protective orders that it has entered."); Pansy $v$ Borough of Stroudsburg, 23 F3d 772, 784 (3d Cir 1994) ("It is well-established that a district court retains the power to modify or lift confidentiality orders that it has entered."); United Nuclear Corp $v$ Cranford Ins Co, 905 F2d 1424, 1427 (10th Cir 1990) ("As long as a protective order remains in effect, the court that entered the order retains the power to modify it, even if the underlying suit has been dismissed.... And modification of a protective order ... is left to the discretion of the district court.") (citations omitted). Even Youngelson, a proponent of the Second Circuit rule, concedes that "[t]he possibility of modifying a protective order exists in the Second Circuit." Youngelson, 1994 Ann Surv Am Law at 275 (cited in note 44).

${ }^{3}$ Of course, a deponent not asserting the privilege, and providing his testimony because of the protective order, gives information that does not directly implicate Fifth Amendment concerns, for he has foregone his constitutional right to "take the Fifth." See text accompanying notes 103-12. 
risk that the protective order will be modified. ${ }^{95}$ And the risk is often large, since the stronger a deponent's case for protecting testimony that reveals criminal behavior, the stronger the government's case for a compelling need justifying an override of the order. ${ }^{96}$

Second, not only are protective orders modifiable under the compelling need rule, but, as discussed above ${ }^{97}$ the standards for modification are not clearly defined. This ambiguity underscores a deponent's uncertainty about the protective order's reliability: not only does he know that the order may be overridden, but he also cannot accurately estimate the risk of such an occurrence. Absent poor legal advice or a foolish personal decision, deponents will likely invoke the Fifth Amendment privilege.

Third, the possibility of leaks of confidential information may persuade deponents to assert the Fifth Amendment privilege rather than rely on a protective order. Opposing parties may leak or threaten to leak incriminating information to law enforcement in order to extract larger concessions in settlements. If a leak does occur, a protective order offers the deponent scant protection against the use of incriminating statements in a grand jury proceeding. ${ }^{98}$

Finally, a protective order usually will not prevent incriminating information from being disclosed at trial; it merely seals

${ }^{95}$ See Note, Using Equitable' Powers to Coordinate Parallel Civil and Criminal Actions, 98 Harv L Rev 1023, 1037-38 (1985) (“' $[B]$ ecause a party cannot completely rely on a protective seal, the seal cannot afford the same protection to the accused as the privilege against self-incrimination. Without formal immunity, an accused would be reluctant, and perhaps foolish, to submit to discovery."); Note, Nonparty Access to Discovery Materials in the Federal Courts, 94 Harv L Rev 1085, 1104 (1981) ("The argument that a deponent will not invoke his privilege if the deposition is governed by a rule 26(c) protective order is surely fallacious.").

${ }^{9}$ Moreover, to the extent that courts grant protective orders merely because all parties agree to one, modification is an appreciable possibility. See Jacqueline S. Guénégo, Trends in Protective Orders Under Federal Rule of Civil Procedure 26(c): Why Some Cases Fumble While Others Score, 60 Fordham L Rev 541, 571-72 (1991):

[T]f both parties stipulate to a protective order, courts rarely question the propriety of the order. . . Because the parties usually draft the order to encompass most, if not all, of the material subject to discovery, presumably judicial resources are saved and discovery proceeds smoothly.

A closer look, however, reveals that this over-inclusiveness tends to make these orders particularly susceptible to later modification.

${ }^{97}$ See text accompanying notes 44-48.

${ }^{98}$ See In re Grand Jury Subpoena, 836 F2d at 1476 ("In the event of a leak of information to law enforcement authorities, a protective order, unlike a grant of immunity, provides no assurance that incriminating statements will not be used against a deponent in a criminal proceeding."); Heidt, 91 Yale I J at 1095 (cited in note 81) ("$[\mathrm{N}] \mathrm{o}$ matter how sweeping the protective order, the danger exists that the other parties or their counsel may violate it and convey to the government the information the witness has provided."). 
the information during civil discovery. ${ }^{99}$ If such information will be made public at trial, the effect of a protective order that induces self-incriminating testimony is to increase pressure on the deponent to settle on the opposing party's terms ${ }^{100}$ (assuming the deponent is a party to the civil litigation) and to impose risks of criminal liability in the future. ${ }^{101}$ For these reasons, a protective order cannot completely protect a deponent's right against selfincrimination and thus may lead him to assert the Fifth Amendment privilege despite the order. ${ }^{102}$

2. Overriding the protective order does not adversely affect deponents' Fifth Amendment rights.

One proponent of the compelling need rule has suggested that allowing a grand jury subpoena to override a protective order "fails to give robust protection to the values inherent in the Fifth Amendment." 103 This view rests upon the premise that a deponent with self-incriminating testimony must either assert the Fifth Amendment privilege and face an "adverse inference" in the civil suit or testify and incriminate himself. ${ }^{104}$ Such a choice, the argument goes, seems to undermine the value judgment inhering in the privilege: that one should neither suffer for his silence nor be forced to implicate himself. However, closer exami-

${ }^{2}$ See Heidt, 91 Yale L $J$ at 1095 (cited in note 81). Unlike an immunity order, which precludes the deponent's responses from being used against him directly or indirectly in a subsequent prosecution,

[a] protective order in a civil case carries no similar assurance. Such an order allows the response, or at least information derived from the response, to spill out at trial, appeal, or some other hearing, where it could be discovered and later used by prosecutors. No protective order could provide the absolute protection . . . require[d] against direct or indirect use by prosecutors. The court can hardly hold all proceedings-including the trial and appeal-in secret, seal all records indefinitely, and prevent all participants from supplying information to the government. Id.

${ }^{100}$ As Youngelson concedes, the protective order may give opposing parties "an enormous bargaining chip in the settlement process." 1994 Ann Surv Am Law at 268 (cited in note 44).

${ }^{100}$ See Heidt, 91 Yale L J at 1097 (cited in note 81) ("When civil liability arises from incriminatory acts, much of the evidence showing the illegal acts should eventually surface at trial, even if effectively suppressed [by a protective order] before then. The evidence revealed at trial is as likely to flag the attention of prosecutors ... as the original discovery responses. ${ }^{\text {). }}$.

${ }^{162}$ See id (" $[\mathrm{A}]$ protective order merely ensures that the circulation of the incriminating responses will be limited temporarily. It is therefore likely to induce a waiver and response only from those seeking to suppress their response temporarily. But temporary suppression should not appeal to many.").

${ }^{103}$ Youngelson, 1994 Am Surv Am Law at 269 (cited in note 44).

${ }^{104}$ Id at 267 (positing that courts "should be reluctant to impose the 'dilemma' of a choice between one's constitutional rights and the imposition of an adverse inferencen"). 
nation reveals that the per se rule does not offend Fifth Amendment rights.

The initial prong of the "dilemma" faced by would-be deponents, the "adverse inference," was addressed by the Supreme Court in Baxter $v$ Palmigiano. ${ }^{105}$ In Baxter, the Court stated that in contrast to criminal cases, "the Fifth Amendment does not forbid adverse inferences against parties to civil actions when they refuse to testify in response to probative evidence offered against them." 106 The court reasoned that drawing the inference posed less of a concern in civil cases than in criminal cases, for in the latter "the stakes are higher and the State's sole interest is to convict." 107 Thus, a deponent asserting the Fifth Amendment privilege during civil discovery may find that his silence carries negative evidentiary value during discovery and trial, and that this result is unquestionably constitutional.

A deponent who wishes to avoid an adverse inference from his silence may do so by testifying or by seeking immunity, and either way the government may obtain testimony useful in the investigation or prosecution of criminally culpable actors. If the deponent fears civil liability more than possible criminal prosecution, he may choose to seek immunity and testify in the civil trial. ${ }^{108}$ In any case, the adverse inference rule advances civil litigation to some extent, ${ }^{109}$ and a grand jury's criminal inquiry is not inevitably frustrated.

Additionally, this "dilemma"110 may weed out frivolous assertions of the Fifth Amendment privilege. Currently, there is little cost to asserting the privilege, since any challenge to a deponent's invocation of the privilege faces significant obstacles. ${ }^{111}$ In-

${ }^{105} 425$ US 308 (1976).

${ }^{106}$ Id at 318.

${ }^{107}$ Id at 318-19.

${ }^{109}$ Indeed, by creating this dilemma, the court may preserve the importance of immunity as a prosecutorial tool.

${ }^{100}$ This may not be true if the deponents are not parties to the civil action. However, in the cases this commentator has surveyed, deponents tend to be officers or directors of corporations. Thus, if plaintiffs in these cases name these agents as defendants in the initial complaint, this problem may be avoided.

${ }^{110}$ While this term may in some sense suggest that a deponent is unfairly penalized for seeking to avoid self-incrimination, it is crucial to remember that in the civil context, the imposition of an adverse inference is a constitutionally permissible outcome. See, for example, In re Phillips, Beckwith \& Hall, 896 F Supp 553, 560-61 (E D Va 1995) ("[T]he Constitution does not guarantee that the exercise of Fifth Amendment rights will be without cost in the civil arena. A party who chooses to assert the privilege against selfincrimination in a civil case must live with the consequences, and "ii]f this be seen as a "price" on the assertion of the privilege, so be it."), quoting United States $v$ Taylor, 975 F2d 404, 404 (7th Cir 1992).

${ }^{11}$ See Heidt, 91 Yale L J at 1071 (cited in note 81) ("Part of the strength of the privi- 
deed, availability of the privilege may provide parties with an incentive to behave strategically in the civil action, the counterbalance of the adverse inference notwithstanding. ${ }^{112}$

\section{Effective Resolution of Civil Disputes}

The third major interest implicated in the conflict between a grand jury subpoena and a protective order is the need to resolve civil disputes justly and efficiently. ${ }^{113} \mathrm{~A}$ major criticism of the per se rule (and, to an extent, the modified per se rule proposed below) is that a deponent apprehensive of grand jury access to testimony will not testify if protective orders may be overridden by a grand jury subpoena. Instead, he will invoke the privilege against self-incrimination, possibly frustrating both the grand jury investigation and the civil litigation. The essence of the argument in favor of sustaining protective orders in the absence of a showing of compelling need is that the deponent's testimony will at least help advance the civil suit, and "the government 'loses' something which it never really had."114

However, this argument for the compelling need rule overstates its case in two ways. First, the protective order facilitates civil litigation only to the extent that it trumps the grand jury subpoena. As noted above, most deponents will be reluctant to stake their freedom from criminal investigation on a potentially modifiable procedural order, especially when the standards for modification are ambiguous. Instead, they are more likely to invoke the privilege against self-incrimination, leading to imposition of the adverse inference. Once again, the example of Martindell, in which the record revealed the protected information to be merely the deponents' assertion of the Fifth Amendment privilege, proves instructive: it suggests that the magnitude of civil

lege as a weapon lies in the difficulty of successfully challenging its assertion. . . . [M]ost assertions of privilege prove highly resistant to attack.").

${ }^{122}$ Id at 1081-82 (noting that "[t]he privilege's many opportunities for use and its resistance to attack render it a potent weapon in the hands of civil defendants" and that "defendants' full exploitation of this constitutional privilege may deny plaintiffs any opportunity for meaningful access to the courts").

${ }^{12}$ See FRCP 1.

"' Youngelson, 1994 Ann Surv Am Law at 271 (cited in note 44). F'or a more concrete formulation of this argument, see Valentin $v$ Richardson, 110 FRD 622, 627-28 (D Mass 1986), in which the court stated that

[i]f the protective order were not issued, Frank Valentin would invoke his Fifth Amendment privilege against self-incrimination at the deposition. In that event, neither the District Attorney nor the litigants to this civil case would have the benefit of his evidence. If the protective order were to issue and Frank Valentin testified in reliance on its protections, the District Attorney would not have the benefit of [his] evidence but the parties to the instant civil case would. 
dispute resolution facilitated by the compelling need rule may be small.

Indeed, both the per se rule and the modified rule proposed by this Comment create an incentive for deponents either to testify-whether or not under a grant of immunity-or to invoke the privilege. If the deponent chooses to testify, the civil action will advance and the grand jury will get the information it seeks. ${ }^{115}$ Alternatively, if he invokes the privilege, the adverse inference, from which opposing parties may draw evidentiary value, may be sufficient to aid the plaintiff in establishing a prima facie case, or perhaps even liability. ${ }^{116}$

Moreover, district courts may employ a number of procedural tools in order to protect Fifth Amendment rights and to "ensure successful resolution of a civil action which is threatened by a deponent's privileged silence."117 One such device is a stay of civil proceedings until the grand jury investigation is complete. ${ }^{118}$ Because defendants will seldom assert the privilege after the grand jury investigation is complete, the civil dispute may ultimately be concluded without extraordinary delay or prejudice to

\footnotetext{
${ }^{115}$ Particularly where the order is overinclusive and protects information which a deponent would consider non-incriminating, and for which he would not assert the privilege, the grand jury gets information under the subpoena-favoring rules that it would not have received under the compelling need rule. This possibility is not farfetched: in In re “Agent Orange" Product Liability Litigation, 821 F2d 139, 142 (2d Cir 1987), for example, the protective order covered any and all documents produced during discovery.

${ }^{115}$ See, for example, United States Department of Treasury v Lopez, 960 F2d 958, 965 (11th Cir 1992) (holding that while the refusal to testify may not be the sole basis of a prima facie case, the adverse inference drawn therefrom could be used along with other evidence to establish a prima facie case); Pagel, Inc v SEC, 803 F2d 942, 946-47 (8th Cir 1986) (finding that in a public administrative proceeding, the SEC could take the adverse inference into account, along with other relevant factors, in determining the appellant's liability under securities law).

${ }^{12}$ In re Grand Jury Subpoena, 836 F2d at 1476.

${ }^{218}$ Id (stating that stays have the "salutary effect of minimizing the conflict between criminal investigations and fair discovery in civil litigation"); Shaffer $v$ United States, 528 F2d 920, 922 (4th Cir 1975) (advocating the use of stays to protect civil discovery from future criminal use); Heidt, 91 Yale L J at 1133-34 (cited in note 81) ("[S]taying the plaintiff's discovery requests ... until after the conclusion of the criminal trial" extinguishes the defendant's need to invoke the privilege, since the "practical pressure on the criminal defendant to invoke regardless of guilt or innocence will have diminished upon the conclusion of the criminal trial.").

It is worth noting that the Constitution does not require that courts stay civil proceedings until the specter of criminal prosecution has faded. See Keating $v$ OTS, 45 F3d 322, 326 (9th Cir 1995); SEC v Dresser Industries, Inc, 628 F2d 1368, 1375 (DC Cir 1980); In re Phillips, Beckwith \& Hall, 896 F Supp 553, 557 (E D Va 1995). Instead, trial courts exercise discretion in determining whether to stay such proceedings. See Dresser Industries, $628 \mathrm{~F} 2 \mathrm{~d}$ at 1375 (" $[\mathrm{A}]$ court may decide in its discretion to stay civil proceedings, postpone civil discovery, or impose protective orders and conditions when the interests of justice seem[ ] to require such action."), quoting United States $v$ Kordel, 397 US 1, 12 n 27 (1970).
} 
the plaintiff. ${ }^{119}$ Indeed, the outcome of the civil dispute may be more accurate than if a stay were not issued. Thus, although a stay may prolong civil litigation, it may also strike a needed balance between the interests of the plaintiff and the defendant.

A second mechanism to encourage the timely resolution of a civil action is to shift the burden of proof to a defendant asserting the privilege against self-incrimination when such assertion significantly contributes to the plaintiff's failure to present a prima facie case. ${ }^{120}$ This would ensure that the defendant could not succeed on a motion to dismiss merely because of aggressive invocation of the privilege.

Prompt resolution of a civil proceeding is further facilitated by two factors that may deter frivolous assertions of the privilege. First, imposing the adverse inference forces deponents to weigh the potential costs of remaining silent on the stand, where previously the privilege could be invoked with impunity. Second, in some cases a pretrial hearing on the soundness of such assertions may serve a gatekeeper function by eliminating frivolous invocations. ${ }^{121}$

\section{A HaRMONIZING RULE: THE REBUTtable PRESUMPTION OF GRAND JURY SUPERIORITYY}

\section{A. A Modified Per Se Rule}

What is striking about both the compelling need and per se rules is their failure to identify adequately and balance appropriately the civil and criminal interests that this issue implicates. Rather than settle for one of two unsatisfying choices, this Com-

\footnotetext{
${ }^{119}$ See Heidt, 91 Yale L J at 1133-34 (cited in note 81), for ways in which the burden on the plaintiff may be lightened if a stay is ordered. Of course, if a defendant asserts the privilege after the completion of the grand jury proceeding in order to be obstructive, the remedy of burden shifting, described below, may apply.

${ }^{202}$ Id at 1107-08 (proposing that "when use of the privilege by defendants . . . contributes substantially to the plaintiff's failure of proof, the court should place on the defendants the burden of showing that they have not engaged in the conduct alleged by the plaintiff'). This remedy is warranted not only by the general notion that equitable factors should govern the allocation of the burden but also by the probability that corporate defendants in complex civil cases are more likely to be able to learn about the conduct of their employees who invoke the Fifth Amendment than are opposing plaintiffs. Id at 1128-29.

${ }^{121}$ See In re Grand Jury Subpoena, 836 F2d at 1476 ("In a few cases, a pretrial hearing by the district court into the validity of a claim of self-incrimination may expose fanciful or frivolous assertions of the privilege."); National Acceptance Co of America v Bathalter, 705 F2d 924, 927 (7th $\mathrm{Cir}$ 1983) ( ${ }^{\circ} \mathrm{Of}$ course, validity of the assertion hinges not on the witness's say so alone: the trial judge must determine whether the witness's silence is justified."). But see Heidt, 91 Yale L $J$ at 1071 (cited in note 81) (noting that while "assertion[s] of the privilege may be attacked" on several grounds, such attacks usually fail). See also notes 110-12 and accompanying text.
} 
ment argues that a new rule, incorporating the better features of both, should be adopted.

This rule would create a rebuttable presumption that a grand jury subpoena overrides a protective order. The presumption would be rebutted, and the protective order maintained, when a party to a civil action persuaded the judge issuing the order that each of the following conditions were satisfied: (1) the aggregated public and private interests in the resolution of the civil action outweigh the public interest in giving the grand jury all possible information; (2) the failure to maintain the order will jeopardize resolution of the civil action; and (3) the alternatives to preserving the protective order (stays, for example) are not appropriate. Several ancillary requirements should also be observed. First, before sustaining a protective order, courts should ensure that the order does not further possible criminal activity (that is, testimony is not protected merely to shield evidence with criminal implications from governmental view). Additionally, courts should ascertain that the protected testimony does not consist merely of an assertion of the Fifth Amendment privilege.

\section{B. Valuation of Civil and Criminal Interests}

The proposed rule is based on a more sophisticated conception of the interaction of civil and criminal law than courts have yet presented. The standard rationale for permitting a grand jury subpoena to override a protective order is the relatively greater magnitude of the public interest involved in the grand jury's criminal investigation, as opposed to the relatively narrower interests at stake in civil litigation. ${ }^{122}$ While it is difficult to compare the value of criminal investigation to that of resolved civil litigation, in most cases the public interest in ascertaining the scope and agents of criminal activity does indeed outweigh the private interests involved in civil litigation. This follows from the notion that the prosecution and punishment of crimes directly protect the public from malevolent actors, while civil litigation generally affects only the interests of private parties. This analysis highlights the inadequacy of the compelling need rule: by presumptively favoring a protective order over a grand jury subpoena, it fails to recognize that more often than not, citizens are

\footnotetext{
${ }^{12}$ See, for example, Nixon $v$ Fitzgerald, 457 US 731, 754 n 37 (1982) (“The Court has recognized before that there is a lesser public interest in actions for civil damages than, for example, in criminal prosecutions."); United States $v$ Nixon, 418 US 683, 711-12 \& n 19 (1974) (grounding holding on importance of evidence in criminal trials, while stating that civil actions raise questions not presented for decision).
} 
better off when crimes are investigated and prosecuted than when civil litigation is resolved.

Yet to the extent that deference to the grand jury reflects a desire to promote people's overall welfare, courts should weigh the countervailing public and private interests in civil dispute resolution against the grand jury's interest in access to information. ${ }^{123}$ Indeed, it would disserve the policies underlying grand juries' powers to allow access to information even when other substantial public interests would be harmed. The singular flaw of the per se rule thus becomes clear: it cannot accommodate the eminently reasonable proposition that people in certain situations prefer to resolve civil litigation rather than advance criminal inquiries.

This suggests that a different balance should be struck ${ }^{124}$ in cases like In re Grand Jury Subpoena Duces Tecum Dated April 19, 1991. ${ }^{125}$ Under the per se rule, creditors, employees, and the public would have suffered from the uncertainty about Eastern's survival.

As the proposed rule demonstrates, however, maintaining the protective order in this case would have advanced broader public and private interests. First, Eastern's bankruptcy court proceedings involved numerous creditors, who claimed that Eastern Airlines owed them billions of dollars. ${ }^{126}$ Thousands of employees' jobs, as well as the business of the traveling public, depended on swift resolution of the proceedings. ${ }^{127}$ These groups brought significant concerns to the civil litigation.

Second, failure to maintain the order would have jeopardized resolution of the civil litigation. ${ }^{128}$ All airlines involved informed the bankruptcy examiner that without the assurance of confidentiality, they would unequivocally refuse to produce any informa-

\footnotetext{
${ }^{123}$ For a partial recognition of the need to evaluate comparative strei'gths of c1;il and criminal interests in this context, see Chemical Bank v Affiliated FM Ins Co, 154 FRD 91, 94 (S D NY 1994) (citation omitted):

The role of the federal courts in law enforcement, exemplified by the Federal Criminal Code[,] and in enforcing Grand Jury subpoenas argues in favor of making significant information available to enforcement authorities absent a countervailing showing that the need for the information for such purposes is outweighed by the need for protecting expectations of confidentiality under [protective orders].

${ }^{22 x}$ It is critical to note that striking this balance at all requires courts both to recognize the full breadth of interests in civil litigation and to compare relative weights of civil and criminal interests-neither of which they explicitly do now.

$1 \approx 945$ F2d 1221 (2d Cir 1991). For a more complete discussion of the case, see text accompanying notes 17-20.

${ }_{128}^{28}$ Id at 1222.

${ }^{127}$ Id.

${ }^{123}$ Id.
} 
tion. ${ }^{129}$ Eastern's management and union were "bitter[ly]" litigating over several of Eastern's pre-filing transactions; had the protective order not been issued, the examiner's investigation into these transactions would have been "seriously delayed."130 And all parties to the proceeding, as well as the judge, sensed that "time was of the essence," and that Eastern was a "wasting asset." ${ }^{\prime 31}$ For precisely this reason, alternatives such as stays would have produced precisely the result to be avoided, namely delay of Eastern's reorganization.

Regarding the ancillary requirements of the modified per se rule, preserving the order would not have furthered any criminal activity, since all allegedly fraudulent transactions at issue had occurred prior to Eastern's filing. ${ }^{132}$ And while the record does not indicate whether any of the more than one hundred witnesses ${ }^{133}$ deposed by the examiner asserted the Fifth Amendment privilege, it is highly unlikely that this would have been the case. The Second Circuit's opinion indicates that soon after the witnesses gave their testimony, the examiner made public his findings, ${ }^{134}$ that the witnesses would offer possibly incriminating testimony given the probability of public access seems implausible.

Thus, by preserving the protective order and resolving the civil dispute, the proposed rule would have better served the public interest, for the parties and public may have been affected more as consumers and taxpayers than as citizens interested in prosecuting crime. ${ }^{135}$

${ }^{120} \mathrm{Id}$.

${ }^{130} \mathrm{Id}$.

${ }^{131} \mathrm{Id}$.

${ }^{132}$ The district court evaluating the bankruptcy examiner's protective order determined that it violated the public policy against agreements to conceal information regarding commission of crimes. Id at 1223. As the Second Circuit correctly noted, however, this approach "would logically require the nullification of every protective order because all protective orders may conceivably result in the withholding of evidence from the government." Id at 1225.

${ }^{133}$ These witnesses were either third parties or employees or officers of one of the airlines involved in Eastern's bankruptcy proceeding. Id at 1223.

${ }^{134}$ Id.

${ }^{135}$ This conception of "preferences" holds in many parallel contexts, for often what one desires depends on "where one sits." See, for example, Cass R. Sunstein, Social Norms and Social Roles, 96 Colum L Rev 903, 924 (1996) ("ITn your capacity as a citizen, you might urge a result ... that is quite different from what you seek through your market behavior in your capacity as a consumer."); Cass R. Sunstein, Incommensurability and Valuation in Law, 92 Mich L Rev 779, 784 (1994) ("Distinctions among kinds of valuation are highly sensitive to the particular setting in which they operate. People do not value goods acontextually. In one setting ... the prevailing kinds of valuation might be quite different from what they are elsewhere."). See also Hughes, 47 Vand L Rev at 585 (cited in note 1). In arguing for coordinated criminal, civil, and administrative enforcement of regulatory laws, the author notes that 
The notion that that civil interests may outweigh criminal interests can be further illustrated in the hypothetical case of an insolvent savings and loan association. Consider a civil action in which directors of a failed savings and loan give testimony that is both necessary to resolution of the suit and useful in a concurrent grand jury investigation into the directors' possible criminal activity. The testimony is covered by a protective order, but the grand jury is seeking to override that order. When the choice must be made between resolving the civil suit by maintaining the protective order or giving the grand jury access to the testimony by overriding the order, it is quite possible that the aggregated public and private interests in settling the affairs of the failed institution might outweigh the public interest in prosecuting the directors. People acting in their roles as taxpayers (who would otherwise have to bail out the savings and loan), as consumers (of future financial services, which may become somewhat more expensive without resolution), or even as interested private parties (if individuals themselves lost money in the savings and loan) may prefer to conclude the civil suit, rather than to advance marginally the criminal investigation. This example suggests that although criminal interests generally outweigh civil interests, under certain circumstances the latter should prevail. This balance between the two simply is not recognized by either the compelling need or per se rule.

Mass tort cases provide another example. The public interest in resolving mass tort litigation may outweigh the interest in prosecuting criminal actors responsible for mass tort injuries. This is particularly the case where sandbagging the civil litigation precludes compensation for hundreds, possibly thousands, of plaintiffs who would otherwise require some form of public insurance. Additionally, these cases, once concluded, may benefit the public and defendants by outlining rights and duties under tort law. ${ }^{136}$

[T]he administrative, regulatory nature of modern government serves goals that are often as urgent as the traditional special importance perceived in criminal investigations. Health, environmental pollution, commercial probity, and protection of the public from abuse of contractual relations with the government are examples of areas in which the public interest is scarcely any less potent than in those sectors protected by traditional criminal law prohibitions.

Id. The principle implicit in Hughes's analysis, and relevant here, is that civil interests may be more compelling than the criminal interests that spring from similar situations.

${ }^{136}$ While precedential value may be difficult for courts to assess, it is not so ethereal a concept that they should ignore it. See generally Louis Kaplow, Rules Versus Standards: An Economic Analysis, 42 Duke L J 557, 577-79, 611-16 (1992) (analyzing the effects of precedent on predictability of legal rules and standards). 
Because other situations will likely be as compelling as the Eastern Airlines bankruptcy, the savings and loan hypothetical, and mass tort cases, the presumptive strength of the grand jury subpoena should be tempered by consideration of the interests enmeshed within civil litigation. Explicit valuation of civil and criminal interests lends support to the notion that a subpoena promulgated by a grand jury should generally, but not always, supersede a protective order. In most conflicts between a subpoena and a protective order, the proposed rule would allow the grand jury to obtain needed information in determining whether criminal activity has transpired, since the public interest in criminal investigation generally outweighs the interests in civil dispute resolution. Thus, the demands of law enforcement would be met.

\section{Advantages and Disadvantages}

The proposed rule would avoid many of the criticisms leveled earlier against the compelling need rule, ${ }^{137}$ one of which was the lack of judicially manageable standards for determining when to override a protective order. The proposed rule sets out explicit standards in order to guide judicial determination of whether to maintain the protective order. It requires valuation of civil and criminal interests, assessment of whether the protective order will materially advance civil litigation, and full consideration of the alternatives to the protective order. Because a judge issuing a protective order presumably has firsthand knowledge of both the interests at stake in and the expected progress of the civil litigation, he can apply the proposed rule with relatively sufficient information on each of the factors. The modified per se rule thus would result in wiser, more consistent exercises of judicial discretion. Additionally, the rule would better serve prosecutors than the compelling need rule. The presumption it establishes entails a value judgment that, in most cases involving competing civil and criminal interests, the latter outweighs the former. Hence grand juries will more often receive critical, relevant information.

Moreover, a prosecutor would no longer face the tension between keeping the subject of the grand jury investigation secret and revealing enough information about it to show a compelling need, since the civil litigant seeking to maintain the protective order would have the burden of demonstrating that the necessary conditions are satisfied. This burden would not prove onerous to a moving party, as he would have access to enough information

${ }^{137}$ See generally Part I.B. 
needed to meet each of the conditions, ${ }^{138}$ and could quite possibly obtain the assistance of opposing parties who might share an interest in expediting the civil proceeding.

Similarly, creating a presumption in favor of the grand jury subpoena would alleviate the "Hobson's choice" problem. ${ }^{139} \mathrm{~A}$ district judge issuing a protective order and then evaluating a grand jury subpoena would no longer be forced into the dilemma of either dashing a deponent's expectation that his testimony would be protected (by rescinding or modifying the protective order) or inhibiting a criminal prosecution (by maintaining the order). Rather, he would merely decide whether or not the circumstances in the civil litigation were such that the protective order should be maintained, the presumption notwithstanding.

Finally, courts would have an incentive to scrutinize stipulated protective orders more closely prior to issuance. ${ }^{140}$ These orders tend to be overinclusive to the extent that all or most materials produced are protected, regardless of materiality or relevance, or of possible nonparty (for example, government or general public) interests in access. While courts typically enter stipulated protective orders without critically evaluating them, ${ }^{141}$ under the proposed rule they would have an incentive to limit their scope appropriately. A district judge cognizant of the possibility that a grand jury will subpoena information covered by a protective order will be less likely to "rubber stamp" the order. Rather, he will keep confidential material for which the parties' civil interests outweigh potential criminal interests, and exclude from protection materials in which nonparties have more sub-

${ }^{138}$ See Parts III.A-B.

${ }^{20}$ See notes 49-50 and accompanying text.

${ }^{140}$ Especially in complex cases, litigants may stipulate to a protective order, specifying that information made available by either party during discovery will be exchanged contingent on substantial restrictions on the outside disclosure of any materials. See Richard L. Marcus, Myth and Reality in Protective Order Litigation, 69 Cornell L Rev 1, 9 (1983) (Stipulated protective orders "usually provide 'umbrella' protection for all materials designated confidential by the party producing them," and "have become the norm in many areas of federal practice."). See also Guénégo, 60 Fordham L Rev at 561 (cited in note 96) ("B]efore two or more corporate entities square off in the judicial arena, they will frequently stipulate as to a blanket or umbrella protective order.").

"'See Guénégo, 60 Fordham L Rev at 562-63 (cited in note 96) ("[B]ecause stipulated protective orders appear to serve [Federal] Rule [of Civil Procedure] 1 interests, most courts sign the order without engaging in a good cause analysis and without requiring the parties to demonstrate good cause."); Marcus, 69 Cornell $L$ Rev at 7-8 (cited in note 140) (The "reality of discovery practice [is] the assumption that any use of discovery materials except to prepare for trial is inappropriate," and "[t]he tendency of courts to enter protective orders, sometimes sua sponte, limiting the use of all information produced through discovery to preparation for trial," confirms this assumption.). 
stantial concern. Properly narrowing the scope of protective orders thus may preclude this issue from ever arising. ${ }^{142}$

The rule would also avoid the inflexibility of the per se rule, since presumptions allow discretion where categorical rules afford none. Adoption of the modified per se rule permits a conscious balancing of interests, necessarily resulting in more administrative inconvenience than the per se rule involves. But any inconvenience is more than offset by the advantages of a sharper and more accurate balance of interests.

While the proposed rule avoids many of the weaknesses of the two existing approaches, some difficulties inevitably remain. The first is a practical one: how are deponents and parties to know in advance whether the civil action will involve a substantial enough interest to justify overriding a possible grand jury subpoena (which, at that time, has not yet been obtained)? Why would they enter into protective orders in the first place knowing that, all else being equal, the subpoena would only presumptively trump their interests in confidentiality? This concern, which results primarily from uncertainty in the application of the standard, will be mitigated if the standard is consistently applied. Moreover, if the civil interests at stake are substantial, it is more likely that parties will rely on the protective order and that all disputants will seek to maintain it against the encroachments of the grand jury subpoena. Finally, the proposed rule may reduce information costs to would-be deponents, who must puzzle through the compelling need rule to determine the probability of protective order modification. ${ }^{143}$

A second doubt is marginality. If many deponents assert the Fifth Amendment privilege under any regime allowing modification of the protective order, the proposed rule would matter only at the margin, for those few deponents who do testify. But aside from the obvious value of grand jury access to testimony from those deponents who do testify, clarity is desirable. The fundamental question is what regime one prefers: a vague standard

\footnotetext{
${ }^{142}$ While the Martindell court asserted that the government's broad investigatory powers made overriding the protective order unnecessary, the court missed a central point. The government could obtain information protected in civil discovery by granting immunity to deponents (for instance), but in doing so it would preclude prosecution of the very actors who might be criminally responsible. See Heidt, 91 Yale L $J$ at 1099 (cited in note 81) ("It is no answer to this situation [in Martindell] to say, as the Second Circuit did, that the government may always obtain this information itself by giving immunity. To give immunity to those with the desired information is often to nullify any hope of prosecution.").

${ }^{143}$ See note 46 for the argument that clarity in application of the rule may be a critical factor in inducing testimony.
} 
that promises protection of reliance interests in a protective order (which may, however, break that promise); an inflexible rule that neglects consideration of important civil interests in dispute resolution; or a rule that forthrightly weighs all interests in a conflict and attempts to provide clearer incentives to would-be deponents and parties.

\section{CONCLUSION}

In addressing the conflict between a protective order and a grand jury subpoena, the compelling need and per se rules stand in stark opposition. The former provides that absent a governmental showing of a compelling need, judicial improvidence, or extraordinary circumstances, the protective order must be maintained. The latter mandates that the grand jury subpoena always prevail. A modified per se rule, incorporating the advantages of both, would allow district court judges to maintain protective orders against grand jury subpoenas where interests in resolving the civil dispute outweigh the interests in criminal investigation. This rule reflects an explicit willingness to compare civil and criminal interests. Such valuation is acutely needed in this context, where the fundamental question in each conflict is whether the protective order or grand jury subpoena serves the more powerful interest. The proposed rule would produce results more closely calibrated to overall public welfare (which is, after all, the animating concern in criminal investigations), and would ensure that courts do not sacrifice the appropriate balance between civil and criminal interests in order to achieve a foolish consistency. 
